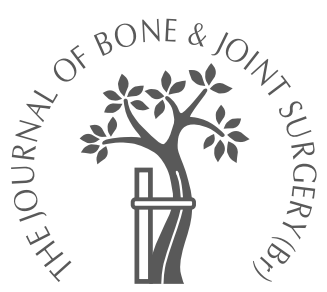

N. S. Tumia, A. J. Johnstone

From Department of Orthopaedic Surgery, University of Aberdeen, Aberdeen, Scotland

\title{
Regional regenerative potential of meniscal cartilage exposed to recombinant insulin-like growth factor-I in vitro
}

It is well recognised that meniscal tears situated within the inner, avascular region do not heal. We investigated the potential effect of insulin-like growth factor-I (IGF-I) in promoting regeneration of meniscal tissue in the inner, middle and outer zones of the meniscus. Sheep menisci were harvested and monolayer cell cultures prepared. Various concentrations of IGF-I were used in the presence or absence of $10 \%$ fetal calf serum (FCS). We measured the uptake of radioactive thymidine, sulphur, and proline to assess cell proliferation and formation of extracellular matrix (ECM). IGF-I, in the presence or absence of FCS, increased the formation of DNA and ECM in all meniscal zones. However, the response of the cells from the avascular zone was greater than that from the vascular zone. Our findings indicate that fibrochondrocytes cultured from avascular meniscal tissue have the ability to regenerate when exposed to anabolic cytokines such as IGF-I.

The meniscus is an integral component of the knee and makes a major contribution to its biomechanics. It protects the articular cartilage both by redistributing joint loads and through shock absorption. ${ }^{1-4}$ Meniscectomy alters the normal biomechanics of the knee and accelerates the development of osteoarthritis in most patients. ${ }^{5-10}$

Tears are by far the commonest disorder affecting the meniscus especially in young and middle-aged active adults. ${ }^{10,11}$ Their management varies according to many factors including the size and the site of the tear. ${ }^{12,13}$ The work of $\mathrm{King}^{14}$ in 1936 and, more recently, that undertaken by other researchers, ${ }^{15-17}$ has shown that meniscal healing depends mainly on the vascularity of the zone which has been injured. The peripheral zone has good healing potential, whereas tears in the avascular zone rarely heal.

Several growth factors are involved in the repair and regeneration of musculoskeletal tissues. ${ }^{18-20}$ Insulin-like growth factor-I (IGF-I) is a major mediator in all stages of wound healing, including inflammation, and its absence dramatically impairs healing in most connective tissues. $^{21-23}$

Our aim was to assess the regenerative potentional of meniscal cells (fibrochondrocytes) harvested from the inner, middle, and outer regions of the meniscus when exposed to IGF-I in a dose-dependent manner. In particular, we wished to investigate whether or not cells from the avascular regions of the meniscus had the ability to proliferate and to produce extracellular matrix (ECM), in a manner similar to those of the vascular region, when exposed to IGF-I in vitro.

\section{Materials and Methods}

We obtained 12 lateral menisci from six sheep from the local abbatoir. The animals were of mixed sex and aged between six and 12 months. After removing the highly vascular anterior and posterior horns, and the peripheral capsular attachments, the menisci were divided radially into slices $5 \mathrm{~mm}$ in size. Each radial slice was then divided into three equally spaced zones $3 \mathrm{~mm}$ thick: an inner (whitewhite zone), middle (red-white zone), and outer (red-red zone). All the pieces were grouped according to their zone and digested in $0.02 \%$ collagenase (GIBCO; Invitrogen Ltd, Paisley, UK) for 14 hours at $37^{\circ} \mathrm{C}$ to release the cells from the surrounding ECM. The digests were filtered to remove any undigested material using cell strainers with a pore size of $70 \mu \mathrm{m}$ (Falcon BD; Fred Baker Scientific, Cheshire, UK). The filtrates were then centrifuged at $1300 \mathrm{rpm}$ for ten minutes to separate the cells. The pellets of cells were re-suspended and cultured in $75 \mathrm{~cm}^{2}$ flasks (Greiner Bio-one Ltd, Gloucestershire, UK) containing Dulbecco's Modified Eagle's medium (DMEM; GIBCO, Invitrogen Ltd) supplemented with 10\% fetal calf serum (FCS; Globepharm Ltd, Surrey, 

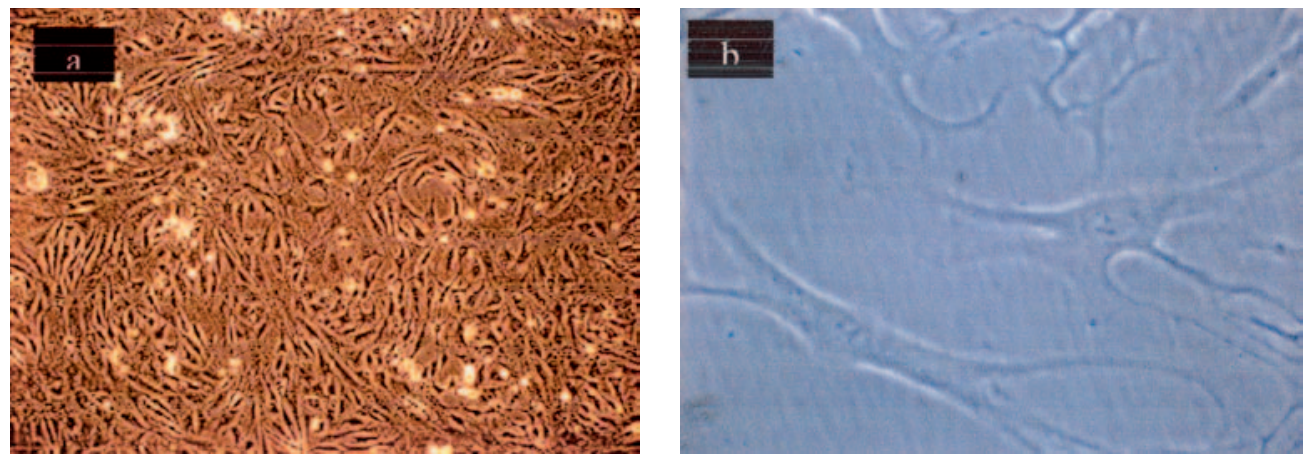

Fig. 1

Photomicrographs of phase-contrast images of confluent monolayer primary cell cultures of fibrochondrocytes obtained from the inner zone of the sheep meniscus a) at x11 and b) at x72 magnification showing the rounded and spindle-shaped cell types.

UK), $0.1 \%$ penicillin/streptomycin (100 U/ml and $100 \mu \mathrm{g} /$ $\mathrm{ml}$, respectively; GIBCO, Invitrogen Ltd) and $50 \mu \mathrm{g} / \mathrm{ml}$ of ascorbic acid (Sigma-Aldrich Ltd, Poole, UK). The cultures were kept in a $\mathrm{CO}_{2}$ incubator $\left(5 \% \mathrm{CO}_{2}\right.$ and $95 \%$ air $)$ at $37^{\circ} \mathrm{C}$.

Once confluent, the cells were trypsinised and randomly divided into two different groups, one containing medium supplemented with $10 \%$ FCS and the other containing serum-free medium. They were placed in 96-well plates (Greiner Bio-one) at a cell density of $2 \times 10^{4}$. Recombinant human IGF-I (R\&D Systems Inc, Oxon, UK) was used at concentrations of 0 (control), 1, 10, 100 and $200 \mathrm{ng} / \mathrm{ml}$, and the experiments were performed in triplicate. The cells were exposed to IGF-I for 48 hours in total.

Assessment of cell proliferation. This was measured by the incorporation of radiolabelled thymidine $\left({ }^{3} \mathrm{H}\right.$-thymidine; Amersham Biosciences Ltd, Bucks, UK) into newly-formed DNA. In the proliferation experiments, $5 \mu \mathrm{Ci} / \mathrm{ml}$ of ${ }^{3} \mathrm{H}$-thymidine were added to the medium along with the IGF-I. The experiments were carried out in triplicate and the results were compared with control samples.

Assessment of the formation of ECM. This was made by measuring the incorporation of radioactive sulphur $\left({ }^{35} \mathrm{SO}_{4}\right.$; Amersham Biosciences Ltd) into newly-formed glycosaminoglycans (GAGs), and the incorporation of radiolabelled proline $\left({ }^{14} \mathrm{C}\right.$-proline; Amersham Biosciences Ltd), into newly-formed proteins. We added together $5 \mu \mathrm{Ci} / \mathrm{ml}$ of ${ }^{35} \mathrm{SO}_{4}$ and $0.5 \mu \mathrm{Ci} / \mathrm{ml}$ of ${ }^{14} \mathrm{C}$-proline along with specific concentrations of IGF-I according to the experimental design. The experiments were carried out in triplicate and the results were compared with control samples.

Scintillation counting. After 48 hours of exposure to IGF-I and the radioactive precursors, the culture medium was removed and the cells washed three times with phosphatebuffered saline (PBS;GIBCO, Invitrogen Ltd) to remove unincorporated radioactive precursors. The fibrochondrocytes present in each well were lysed using $0.2 \%$ lysis buffer, and a sample of this digestate was added to $2 \mathrm{ml}$ of scintillation fluid and the incorporation of the radioactive

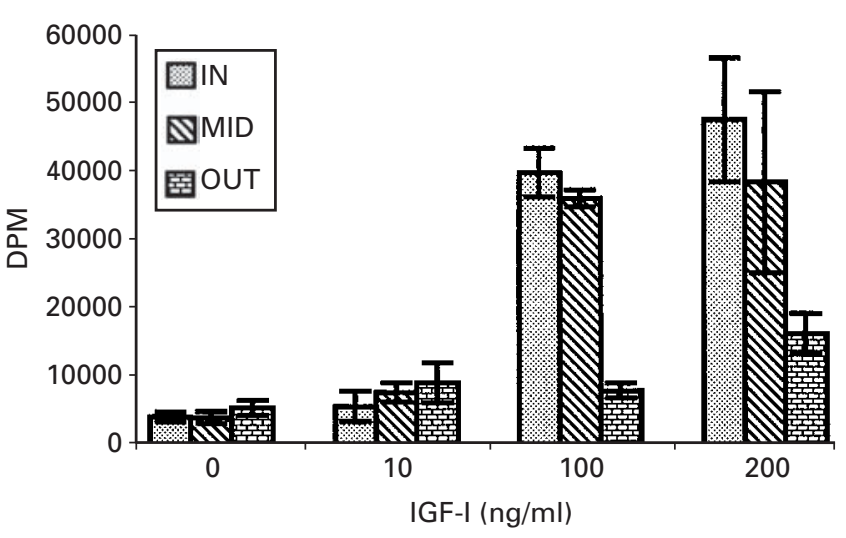

Fig. 2

The geometric mean (with $95 \% \mathrm{Cl}$ ) uptake of ${ }^{3} \mathrm{H}$-thymidine incorporated into newly-formed DNA in the cells of the inner, middle and outer zones of the meniscus in serum-supplemented medium.

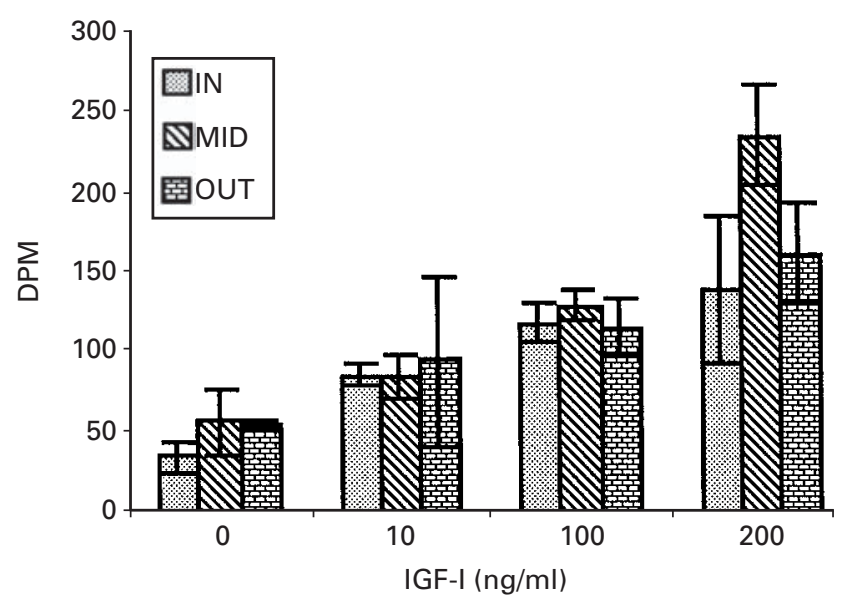

Fig. 3

The geometric mean (with $95 \% \mathrm{Cl}$ ) uptake of ${ }^{35} \mathrm{SO}_{4}$ incorporated into newly-formed GAGs of the ECM of the inner, middle and outer zones of the meniscus in serum-supplemented medium. 
Table I. The geometric means uptake of precursor ( $\pm 95 \% \mathrm{CI}$ ) when exposed to various concentrations of IGF-I in serum-supplemented experiments

\begin{tabular}{|c|c|c|c|c|c|c|c|c|c|}
\hline \multirow{2}{*}{$\begin{array}{l}\text { IGF-I } \\
\text { (ng/ml) }\end{array}$} & \multicolumn{3}{|l|}{ Thymidine } & \multicolumn{3}{|l|}{ Sulphur } & \multicolumn{3}{|l|}{ Proline } \\
\hline & $\ln$ & Mid & Out & In & Mid & Out & In & Mid & Out \\
\hline 0 & $4082(713)$ & 4002 (862) & $5423(1118)$ & $35(9)$ & $56(20)$ & $54(2)$ & 50837 (10169) & $54593(12602)$ & 73220 (14021) \\
\hline 1 & $6342(2225)$ & $7829(1353)$ & 9531 (2937) & $54(13)$ & $65(9)$ & $126(58)$ & $44126(3500)$ & 10787 (1348) & 26424 (20816) \\
\hline 10 & $5684(3581)$ & 7772 (1252) & 9135 (1109) & $85(7)$ & $84(14)$ & $95(53)$ & $111825(16750)$ & 49979 (5943) & 51095 (43156) \\
\hline 100 & 39869 (9165) & 36118 (13247) & 7922 (2961) & $119(13)$ & $129(10)$ & $115(17)$ & 134981 (5861) & $159100(11461)$ & 161272 (18629) \\
\hline 200 & $47734(7236)$ & 38530 (6885) & $16386(6786)$ & $140(47)$ & $236(32)$ & $162(30)$ & 186208 (3407) & 167454 (4505) & 175675 (23587) \\
\hline
\end{tabular}

precursor(s) measured (disintegrations per minute (DPM) using a scintillation counter (Wallac 1409; PerkinElmer Life Sciences Ltd, Cambridge, UK). Each sample was read for five minutes.

Statistical analysis. This was performed using SigmaStat for Windows computer software (version 2.03, SPSS UK Ltd, Surrey, UK) under the supervision of our Medical Statistics Department. Statistical significance was assessed using two-way analysis of variance taking into consideration both the effect of the concentration of IGF-I used and the zonal origin of the cells. The results for each group, serum-free and serum-supplemented, were analysed separately. When data were not normally distributed, logarithmic transformation of the data was carried out. Tukey's test for multiple comparisons was performed. We considered a $\mathrm{p}$ value of $<0.05$ to be statistically significant.

\section{Results}

In the primary monolayer cell culture, the cells reached confluence in seven to ten days. They were a mixture of phenotypes; oval or spindle-shaped cells which normally exist in the superficial layer of the meniscus, and round-shaped cells which are found predominantly in the deep layer (Fig. 1).

In the serum-supplemented media group, there was an eight- to ten-fold increase in the uptake of thymidine in the inner and middle zones using concentrations of IGF-I of 100 or $200 \mathrm{ng} / \mathrm{ml}$, compared with the control experiments $(\mathrm{p}<0.001)$. In the outer zone there was a 3.5 -fold increase in the uptake of thymidine at a concentration of IGF-I of $200 \mathrm{ng} / \mathrm{ml}$ ( $\mathrm{p}=0.002$ ) (Fig. 2). The uptake of sulphur increased by between three- and five-fold in all three zones of the meniscus when exposed to a concentration of IGF-I of $200 \mathrm{ng} / \mathrm{ml}$ ( $\mathrm{p}<0.05$ ) (Fig. 3). Similarly, the uptake of radiolabelled proline was increased three-fold in all three zones at concentrations of IGF-I 100 and of $200 \mathrm{ng} / \mathrm{ml}$ ( $\mathrm{p}<$ 0.001; Fig. 4; Table I).

In the serum-free media group, there was a four- to fivefold increase in the uptake of thymidine in all zones of the meniscus $(p<0.05)$ (Fig. 5). The uptake of sulphur was increased by 2.5 -fold in all three zones of the meniscus using concentrations of IGF-I of 100 and $200 \mathrm{ng} / \mathrm{ml}$ (p < 0.05 ; Fig. 6). The uptake of proline was increased by ten- to 16 -fold in all three meniscal zones using concentrations of IGF-I of 10, 100, and $200 \mathrm{ng} / \mathrm{ml}$ ( $\mathrm{p}<0.05$; Fig. 7; Table II).

Overall, in every experiment, there was a statistically significant interaction between the concentration of IGF-I and the meniscal zone $(\mathrm{p}<0.05)$. In addition in both the serumfree and in the serum-supplemented experiments, irrespective of the precursor under investigation, the differences in the mean value of uptake of precursors were statistically

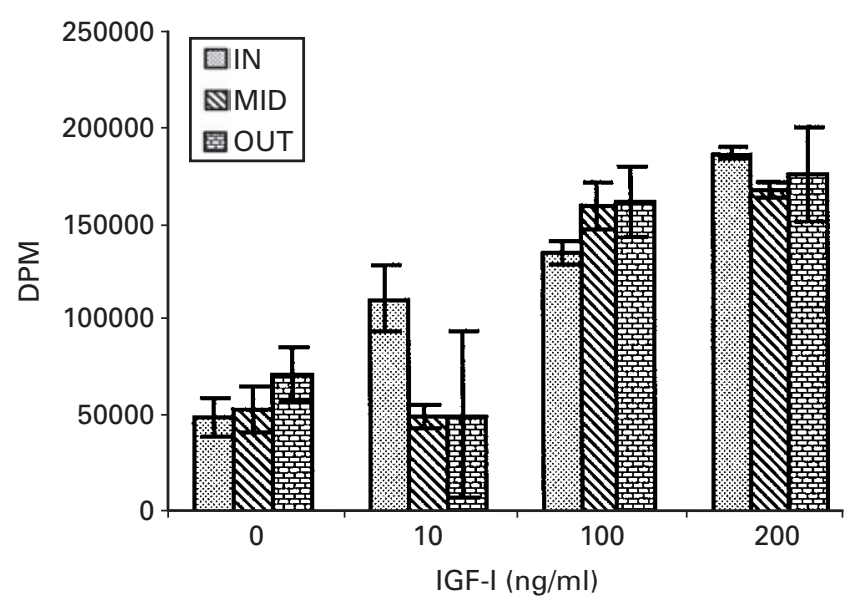

Fig. 4

The geometric means (with $95 \% \mathrm{Cl}$ ) uptake of ${ }^{14} \mathrm{C}$-proline incorporated into newly-formed proteins of the ECM of the inner, middle and outer zones of the meniscus in serum-supplemented medium.

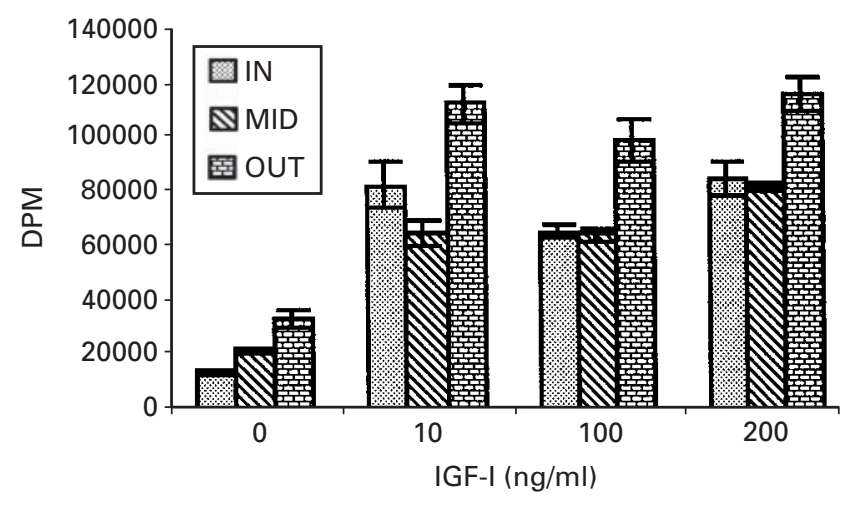

Fig. 5

The geometric mean (with $95 \% \mathrm{Cl}$ ) uptake of ${ }^{3} \mathrm{H}$-thymidine incorporated into newly-formed DNA in the cells of the inner, middle and outer zones of the meniscus in serum-free medium. 


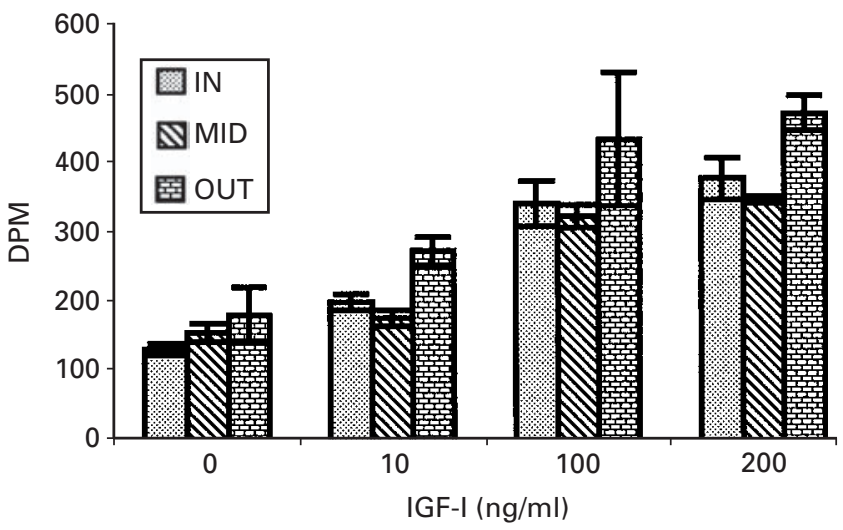

Fig. 6

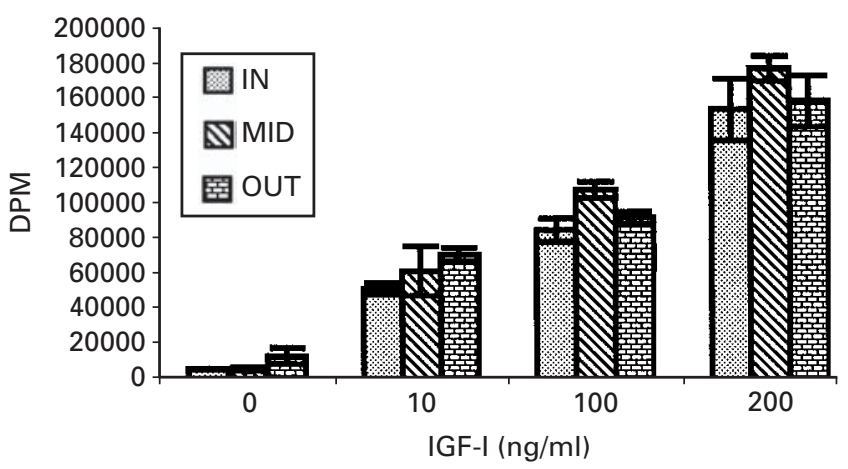

Fig. 7

The geometric mean (with $95 \% \mathrm{Cl}$ ) uptake of ${ }^{35} \mathrm{SO}_{4}$ incorporated into newly-formed GAGs of the ECM of the inner, middle and outer zones of the meniscus in serum-free medium.

The geometric means (with $95 \% \mathrm{Cl}$ ) uptake of ${ }^{14} \mathrm{C}$-proline incorporated into newly-formed proteins of the ECM of the inner, middle and outer zones of the meniscus in serum-free medium.

Table II. The geometric means uptake of precursor $( \pm 95 \% \mathrm{Cl})$ when exposed to various concentrations of IGF-I serum-free experiments

\begin{tabular}{|c|c|c|c|c|c|c|c|c|c|}
\hline \multirow{2}{*}{$\begin{array}{l}\text { IGF-I } \\
\text { (ng/ml) }\end{array}$} & \multicolumn{3}{|l|}{ Thymidine } & \multicolumn{3}{|l|}{ Sulphur } & \multicolumn{3}{|l|}{ Proline } \\
\hline & In & Mid & Out & In & Mid & Out & In & Mid & Out \\
\hline 0 & $13943(637)$ & $21582(622)$ & 32860 (3757) & $133(9)$ & $158(13)$ & $183(40)$ & $5617(508)$ & 5300 (959) & 13002 (4737) \\
\hline 1 & 83031 (9183) & 64974 (4673) & 125209 (6593) & $141(10)$ & $138(6)$ & $183(7)$ & 10439 (8895) & $9619(377)$ & $10988(1623)$ \\
\hline 10 & 82495 (3106) & 64957 (1278) & 112625 (7217) & $203(11)$ & $180(12)$ & $276(21)$ & $51733(3510)$ & $61808(14174)$ & 71512 (3764) \\
\hline 100 & 65262 (6237) & $64210(1741)$ & $99186(5758)$ & 345 (34) & $326(17)$ & 437 (97) & 85259 (6867) & 107901 (4585) & $922253(3804)$ \\
\hline 200 & $85633(5528)$ & $82258(2508)$ & $116221(4206)$ & $380(31)$ & $349(5)$ & $475(25)$ & $153886(17740)$ & 177915 (7293) & 159125 (14923) \\
\hline
\end{tabular}

significant $(\mathrm{p}<0.05)$ at all concentrations of IGF-I and in all meniscal zones.

\section{Discussion}

The sheep meniscus has been shown to have peripheral vascular and inner avascular zones which respond to injuries like those of the human meniscus. ${ }^{24-26}$ In addition, Joshi et $\mathrm{al}^{27}$ reported that the sheep meniscus is an excellent experimental model since its mechanical properties closely match those of the human meniscus.

Studies have shown that 'red-red' tears, which involve the outer meniscus, can heal after surgical repair whereas 'white-white' tears, involving the inner avascular zone, do not. ${ }^{28,29}$ It has been postulated that the lack of certain cytokines or growth factors may account for this variation. Arnoczky, Warren and Spivak ${ }^{30}$ in their experiments on meniscal tears involving the avascular zone in dogs, showed that the introduction of a fibrin clot around a meniscal tear enhanced meniscal regeneration. Ochi et $\mathrm{al}^{31}$ reported that rasping the edge of meniscal tears created in the avascular zone of rabbit menisci increased the production of cytokines which presumably was responsible for improving healing.

We chose IGF-I because of its known stimulatory effect on musculoskeletal soft tissues. Several studies have shown that IGF-I contributes to the healing of tendons ${ }^{18,32,33}$ and repair of articular cartilage. ${ }^{34-37}$ However, there have been no studies in the literature which have explored the role of IGF-I in meniscal regeneration, although a few have investigated the effects of growth factors such as platelet-derived growth factor (PDGF), fibroblast-derived growth factor, and transforming growth factor on meniscal tissue. ${ }^{24,38-41}$ Spindler et $\mathrm{a}^{24}$ reported that unlike cells from the vascular zone, fibrochondrocytes cultured from the inner avascular zone were not stimulated by PDGF. They concluded that the inner zone lacks the ability to regenerate. ${ }^{24}$

In our study, IGF-I was clearly capable of stimulating the activity of fibrochondrocytes in keeping with cell proliferation and formation of ECM in all zones of the meniscus including the avascular zone. In addition, IGF-I stimulated the activity of fibrochondrocytes when used either singly or in combination with $10 \%$ FCS.

Interestingly, IGF-I increased the uptake of thymidine and presumably the formation of DNA more in the inner zone than in the outer zone of the meniscus in the presence of serum.

Our findings indicate that meniscal cells, and more importantly cells from the avascular zone, are capable of responding favourably to the addition of IGF-I. After stimulation with this growth factor, these cells express their intrinsic potential to proliferate and generate new ECM. Finally, our results suggest that it may be possible in the 
future to augment meniscal repair and to advance tissueengineering methods in order ultimately to create meniscal replacements by using suitable growth factors.

This research project was funded by the Scottish Hospital Endowments Research Trust (SHERT). We also thank the Public Health Department of the University of Aberdeen for their statistical advice.

No benefits in any form have been received or will be received from a commercial party related directly or indirectly to the subject of this article.

\section{References}

1. Fithian DC, Kelly MA, Mow VC. Material properties and structure-function relationships in the menisci. Clin Orthop 1990;252:19-31.

2. Redkey WG. Basic biology of the meniscus and response to injury. Instr Course Lect 2000;49:189-93

3. Mow VC, Ratcliffe A, Chern KY, Kelly MA. Structure and function relationships of the menisci and the knee. In: Mow VC, Arnoczky SP, Jackson DW, eds. Knee meniscus: basic and clinical foundations. New York: Raven Press Ltd, 1992:37-57.

4. Proctor CS, Schmidt MB, Whipple RR, Kelly MA, Mow VC. Material properties of the normal medial bovine meniscus. J Orthop Res 1989;7:771-82.

5. Allen PR, Denham RA, Swan AV. Late degenerative changes after meniscectomy: factors affecting the knee after operation. J Bone Joint Surg [Br] 1984;66-B:666-71.

6. Andersson-Molina H, Karlsson H, Rockborn P. Arthroscopic partial and total meniscectomy: a long-term follow-up study with matched controls. Arthroscopy 2002; 18:183-9.

7. Bourne RB, Finlay JB, Papadopoulos P, Andrae P. The effect of medial meniscectomy on strain distribution in the proximal part of the tibia. J Bone Joint Surg [Am] 1984;66-A:1431-7.

8. Hawkins A, McNicholas MJ. Meniscectomy and arthritis. CME Orthop 2001;2:51-6.

9. Hede A, Larsen E, Sandberg H. The long term outcome of open total and partia meniscectomy related to the quantity and site of the meniscus removed. Int Orthop 1992:16:122-5.

10. Hoshikawa Y, Kurosawa H, Fukubayashi T, Nakajimel T, Watarai K. The prognosis of meniscectomy in athletes: the simple meniscus lesions without ligamentous instabilities. Am J Sports Med 1983;11:8-13.

11. Jorgensen U, Sonne-Holm S, Lauridsen F, Rosenklint A. Long-term follow-up of meniscectomy in athletes: a prospective longitudinal study. J Bone Joint Surg [Br] 1987;69-B:80-3.

12. Rubman MH, Noyes FR, Barber-Westin SD. Arthroscopic repair of meniscal tears that extend into the avascular zone: a review of 198 single and complex tears. Am J Sports Med 1998:26:87-95

13. England M, Roos EM, Roos HP, Lohmander LS. Patient-relevant outcomes fourteen years after meniscectomy: influence of type of meniscal tear and size of resection. Rheumatology 2001;40:631-9.

14. King D. The healing of semilunar cartilages. J Bone Joint Surg 1936;18:333-42.

15. Cabaud HE, Rodkey WG, Fitzwater JE. Medical meniscus repairs: an experimental and morphologic study. Am J Sports Med 1981;9:129-34.

16. Teng LH, Gau TL, O'Connor S, Der YC, Barmada R. Healing potential of experimental meniscal tears in the rabbit: preliminary results. Clin Orthop 1991;267:299-305.

17. Takeuchi N, Suzuki Y, Sagehashi Y, et al. Histologic examination of meniscal repair in rabbits. Clin Orthop 1997;338:253-61.

18. Kurtz CA, Loebig TG, Anderson DD, DeMeo PJ, Campbell PG. Insulin-like growth factor I accelerates functional recovery from achilles tendon injury in a rat model. Am J Sports Med 1999;27:363-9.

19. Davidson JM. Wound repair. In: Gallin JL, Goldenstein IM, Snyderman R, eds. Inflammation: basic principles and clinical correlates. New York: Raven Press Ltd, 1992:809-19.
20. Hamon GA, Hunt TK, Spencer EM. In vivo effects of systemic insulin-like growth factor-l alone and complexed with insulin-like growth factor binding protein-3 on corticosteroid suppressed wounds. Growth Regul 1993;3:53-6.

21. Skottner A, Arrhenius-Nyberg V, Kanje M, Fryklund L. Anabolic and tissue repair functions of recombinant insulin-like growth factor I. Acta Paediatr Scand 1990;367(Suppl):63-6.

22. Verhaeghe J, van Bree R, Van Herck E, et al. Effects of recombinant human growth hormone and insulin-like growth factor-l, with or without 17 beta-estradiol, on bone and mineral homeostasis of aged ovariectomized rats. J Bone Miner Res 1996; 11:1723-35.

23. Suh DY, Hunt TK, Spencer EM. Insulin-like growth factor-I reverses the impairment of wound healing induced by corticosteroids in rats. Endocrinology 1992;131:2399403.

24. Spindler KP, Mayes CE, Miller RR, Imro AK, Davidson JM. Regional mitogenic response of the meniscus to platelet-derived growth factor (PDGF-AB). J Orthop Res 1995;13:201-7.

25. Ghadially FN, Lalonde JMA, Wedge JH. Ultrastructure of normal and torn menisci of the human knee joint. J Anat 1983;136:773-91.

26. Ghadially FN, Wedge JH, Lalonde JM. Experimental methods of repairing injured menisci. J Bone Joint Surg [Br] 1986;68-B:106-10.

27. Joshi MD, Suh J-K, Mariu T, Woo SLY. Interspecies variation of compressive biomechanical properties of the meniscus. J Biomed Mater Res 1995;29:823-8.

28. Cooper DE, Arnoczky SP, Warren RF. Meniscal repair. Clin Sports Med 1991;10: $529-48$.

29. Ulrich GS, Arnoczky SP. The basic science of meniscal repair. Techniques in Orthopaedics 1993;8:56-62.

30. Arnoczky SP, Warren RF, Spivak JM. Meniscal repair using an exogenous fibrin clot: an experimental study in dogs. J Bone Joint Surg [Am] 1988;70-A:1209-17.

31. Ochi M, Uchio Y, Okuda K, et al. Expression of cytokines after meniscal rasping to promote meniscal healing. Arthroscopy 2001;17:724-31.

32. Abrahamsson S0. Similar effects of recombinant human insulin-like growth factorI and II on cellular activities in flexor tendons of young rabbits: experimental studies in vitro. J Orthop Res 1997;15:256-62.

33. Hansson HA, Dahlin LB, Lundborg G, et al. Transiently increased insulin-like growth factor I immunoreactivity in tendons after vibration trauma: an immunohistochemical study on rats. Scand J Plast Reconstr Surg Hand Surg 1988;22:1-6.

34. Fortier LA, Mohammed HO, Lust G, Nixon AJ. Insulin-like growth factorenhances cell-based repair of articular cartilage. J Bone Joint Surg [Br] 2002;84-B: 276-88.

35. Fortier LA, Balkman CE, Sandell LJ, Ratcliffe A, Nixon AJ. Insulin-like growth factor-I gene expression patterns during spontaneous repair of acute articular cartilage injury. J Orthop Res 2001;19:720-8.

36. Nixon AJ, Fortier LA, Williams J, Mohammed H. Enhanced repair of extensive articular defects by insulin-like growth factor--laden fibrin composites. J Orthop Res 1999;17:475-87.

37. Worster AA, Brower-Toland BD, Fortier LA, et al. Chondrocytic differentiation of mesenchymal stem cells sequentially exposed to transforming growth factor-beta 1 in monolayer and insulin-like growth factor-l in a three-dimensional matrix. J Orthop Res 2001;19:738-49

38. Webber RJ, Harris MG, Hough AJ Jr. Cell culture of rabbit meniscal fibrochondrocytes: proliferative and synthetic response to growth factors and ascorbate. J Orthop Res 1985;3:36-42

39. Bhargava MM, Attia ET, Murrell GAC, et al. The effect of cytokines on the proliferation and migration of bovine meniscal cells. Am J Sports Med 1999;27:636-43.

40. Webber RJ, Zitaglio T, Hough AJ Jr. Serum-free culture of rabbit meniscal fibrochondrocytes: proliferative response. J Orthop Res 1988;6:13-23.

41. Kumagae Y. Proteoglycan and collagen synthesis of cultured fibrochondrocytes from the human knee joint meniscus. Nippon Seikeigeka Gakkai Zasshi 1994;68:885-94. 